\title{
Changes in Growth and Physiological Parameters of $\times$ Amarine Following an Exogenous Application of Gibberellic Acid and Methyl Jasmonate
}

\author{
Piotr Salachna ${ }^{1, * \mathbb{C}}$, Małgorzata Mikiciuk ${ }^{2}$, Agnieszka Zawadzińska ${ }^{1}{ }^{\mathbb{D}}$, Rafał Piechocki $^{1}$, \\ Piotr Ptak $^{2}$, Grzegorz Mikiciuk ${ }^{1}$, Anna Pietrak ${ }^{1}$ and Łukasz Lopusiewicz ${ }^{3}$ D \\ 1 Department of Horticulture, West Pomeranian University of Technology, 3 Papieża Pawła VI Str., \\ 71-459 Szczecin, Poland; agnieszka.zawadzinska@zut.edu.pl (A.Z.); rafal.piechocki@zut.edu.pl (R.P.); \\ grzegorz.mikiciuk@zut.edu.pl (G.M.); aniusia.pietrak943@gmail.com (A.P.) \\ 2 Department of Bioengineering, West Pomeranian University of Technology, 17 Słowackiego Str., \\ 71-434 Szczecin, Poland; malgorzata.mikiciuk@zut.edu.pl (M.M.); piotr.ptak@zut.edu.pl (P.P.) \\ 3 Center of Bioimmobilisation and Innovative Packaging Materials, Faculty of Food Sciences and Fisheries, \\ West Pomeranian University of Technology, 35 Janickiego Str., 71-270 Szczecin, Poland; \\ lukasz.lopusiewicz@zut.edu.pl \\ * Correspondence: piotr.salachna@zut.edu.pl; Tel.: +48-91-4496-359
}

Received: 5 June 2020; Accepted: 6 July 2020; Published: 8 July 2020

\begin{abstract}
Amarine hybrids are attractive ornamental geophytes grown for cut flower production. Their cultivation is limited due to lesser flowering percentages and lesser bulb weight gain. To optimize the growth and propagation of geophytes, plant growth regulators (PGRs) are used, but so far none have been tested in $\times$ Amarine. We investigated the effect of gibberellic acid $\left(\mathrm{GA}_{3} ; 50,100\right.$, and $200 \mathrm{mg} \mathrm{dm}^{-3}$ ) and methyl jasmonate (MeJA; 100, 500, and $1000 \mu \mathrm{mol} \mathrm{dm}^{-3}$ ) on growth, flowering, bulb yield, and select physiological parameters of $\times$ A. tubergenii "Zwanenburg". PGRs were applied as foliar sprays on the 70th and 77th day after planting. $\mathrm{GA}_{3}$ treatment at $200 \mathrm{mg} \mathrm{dm}^{-3}$ exhibited the greatest leaf number, leaf length, bulb weight, daughter bulb number, $\mathrm{CO}_{2}$ assimilation intensity, greenness index, total sugars, and total protein content in bulbs. GA 3 application at 100 and $200 \mathrm{mg}$ $\mathrm{dm}^{-3}$ accelerated flowering and at 50 and $100 \mathrm{mg} \mathrm{dm}^{-3}$ significantly increased the bulb flowering percentage. MeJA at all tested concentrations prolonged anthesis time and reduced the bulb flowering percentage. $\mathrm{GA}_{3}$ at all concentrations and MeJA at 500 and $1000 \mu \mathrm{mol} \mathrm{dm}{ }^{-3}$ stimulated daughter bulbs formation. $\mathrm{GA}_{3}$, especially at $200 \mathrm{mg} \mathrm{dm}^{-3}$ can improve anthesis and increase $\times$ A tubergenii "Zwanenburg" bulb yield.
\end{abstract}

Keywords: cut flower; bulb propagation; phytohormones; $\mathrm{GA}_{3}$; MeJA; gas exchange

\section{Introduction}

Ornamental plant production is an important horticultural branch. The expansion of the selection with previously unknown species, their hybrids, and new varieties is a key factor for the development of this sector [1]. An important part of flower production is the cultivation and reproduction of bulbous plants [2]. There are more than 800 different botanical genera of ornamental geophytes on the market. Their number systematically increases due to species introduction from natural sites and extensive breeding programs [3,4]. Plants newly introduced to the flower market lack appropriate cultivation technologies and methods of species propagation. Therefore, research is needed to effectively encourage producers to start growing previously unknown plants.

Among bulbous plants, considerable success was achieved in the breeding of Amaryllidaceae interspecific and intergeneric hybrids [5], using for crosses South African species from the genera 
Amaryllis L., Brunsvigia Heister, Clivia Lindl., Cyrtanthus W. Aiton, Haemanthus L., and Nerine Herb. These plants are cultivated for their attractive flowers [6] and as a source of valuable alkaloids with therapeutic effects [7]. Breeding resulted in the nothogenus $\times$ Amarine tubergenii Sealy, a hybrid between Amaryllis belladonna L. and Nerine bowdenii Watson [8]. Inflorescence of $\times A$. tubergenii sets on a long leafless stem and consists of helicoid cymes inflorescence, each with several pink florets (Figure 1a,b). The leaves are dark green, ensiform, form a rosette, and grow directly from bottle-shaped perennial bulbs covered with brown scales (Figure $1 \mathrm{c}, \mathrm{d}$ ). $\times$ A. tubergenii inflorescences demonstrate very good post-harvest durability and are a desirable commodity on the cut flower market [9]. As a result of further intergeneric crosses, many $\times$ Amarine varieties were obtained, differing in floret color, size, and flowering time. Research is lacking on $\times$ Amarine cultivation, which is an obstacle to the wider spread of this prospective ornamental plant.

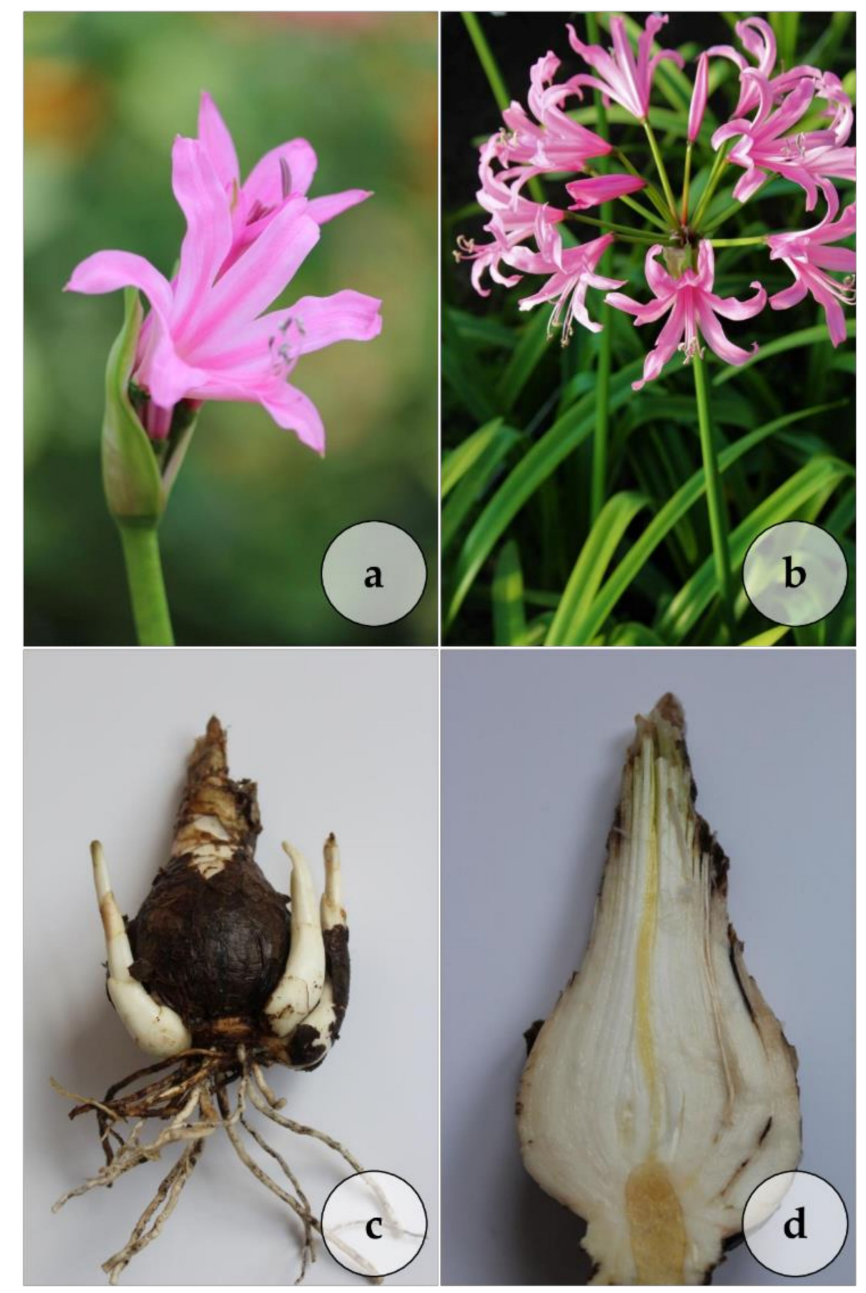

Figure 1. An inflorescence of $\times$ A. tubergenii (a) and in full anthesis (b). Perennial bulb of $\times A$. tubergenii with daughter bulbs (c) and a longitudinal section through a dormant bulb (d).

A. belladonna and $N$. bowdenii species, from which $\times$ Amarine was obtained, differ in the duration of dormancy and growth and development stages. In A. belladonna, the foliage emerges after anthesis (a hysteranthous growth habit), while in N. bowdenii foliage emerges before anthesis (a synanthous growth habit) [10]. In the Northern Hemisphere, after a dormancy period, $\times$ Amarine bulbs first grow leaves in the spring, followed by floral stems in late summer and autumn. After anthesis, the plants become dormant. During this time, the bulbs should be exposed to decreased temperatures for flower primordia initiation. A serious problem in $\times A$. tubergenii cultivation is decreased flowering percentages commonly observed in N. bowdenii [11], a parent plant of the hybrid. The reasons for nonflowering in 
$N$. bowdenii are complex and result from many independent factors, such as inadequate temperature during bulb dormancy and plant growth, undersized bulbs, or insufficient carbohydrate content [12]. The flowering of $\times A$. tubergenii hybrids are irregular and extended in time (unpublished data), which limits their widespread use as a cut-flower crop.

In ornamental plant cultivation, plant growth regulators (PGRs) are used. They are active at exceptionally decreased concentrations and participate in the regulation of growth, anthesis, propagation, and physiological and metabolic processes $[13,14]$. Gibberellins are one of the best known natural phytohormones widely used in horticulture to terminate dormancy [15], stimulate floret formation and development [16], and accelerate or delay plant anthesis [17]. Gibberellins are responsible for stem elongation [18], stimulation of cell division and development of lateral buds [19], and also intensify photosynthesis and respiration [20]. Conversely, jasmonates, including methyl jasmonate (MeJA), are a fairly recently discovered phytohormone class [21]. MeJA is involved in regulating germination [22], morphogenesis [23], and aging [24], as well as the plant response to environmental stresses [25]. The available data from studies on the influence of MeJA on plant growth present divergent results. MeJA shows both growth-stimulating and growth-inhibiting effects [26,27], it can speed up or inhibit anthesis [28,29], and increase or decrease bulbing [30,31].

As there is no information on the use of PGRs in $\times A$. tubergenii cultivation, we assessed the effect of gibberellic acid $\left(\mathrm{GA}_{3}\right)$ and MeJA at different concentrations on $\times$ A. tubergenii morphological traits, anthesis, and bulb yield. To obtain information on potential physiological changes induced by $\mathrm{GA}_{3}$ or MeJA, the study also examined select gas exchange and chlorophyll fluorescence parameters and determined total sugars and total protein content in bulbs. We hypothesized that the applied regulators influenced the growth and physiological condition of $\times$ A. tubergenii plants.

\section{Materials and Methods}

\subsection{Experimental Location, Plant Materials, and Growth Conditions}

The experiment was conducted in an unheated plastic house ( $25 \mathrm{~m}$ in length, $9 \mathrm{~m}$ in width, and $4.7 \mathrm{~m}$ in total height), covered with a double layer of UV-resistant foil, located at the West Pomeranian University of Technology in Szczecin $\left(53^{\circ} 25^{\prime} \mathrm{N}, 14^{\circ} 32^{\prime} \mathrm{E}, 25 \mathrm{~m}\right.$ a.s.l., sub-zone 7a USDA).

Dormant $\times$ A tubergenii "Zwanenburg" bulbs with a 12-14 cm circumference and an average fresh weight of $39.0 \mathrm{~g}$, imported from the Netherlands by Ogrodnictwo Wiśniewski Jacek Junior (Góraszka, Poland), were stored for 3 weeks in dark at $5-8{ }^{\circ} \mathrm{C}$ until planting. Before planting, sorted for disease-free bulbs were treated for $30 \mathrm{~min}$ in a fungicide mixture containing $0.7 \%(\mathrm{w} / \mathrm{v})$ Topsin $\mathrm{M}$ 500 SC (Nippon Soda, Tokyo, Japan, active ingredient: thiophanate-methyl) and 1\% (w/v) Kaptan 50 WP (Organika-Azot Chemical Company, Jaworzno, Poland, active ingredient: Captan). On 14 April, the bulbs were planted individually into black round PVC pots with $15 \mathrm{~cm}$ diameter and a $1.5 \mathrm{dm}^{3}$ capacity, filled with deacidified peat (Kronen, Cerkwica, Poland) (pH 6.3; $16 \mathrm{mg} \mathrm{dm}^{-3} \mathrm{~N}^{-\mathrm{NO}_{3}}, 42$ $\mathrm{mg} \mathrm{dm}{ }^{-3} \mathrm{P}, 19 \mathrm{mg} \mathrm{dm}^{-3} \mathrm{~K}, 1550 \mathrm{mg} \mathrm{dm}^{-3} \mathrm{Ca}, 101 \mathrm{mg} \mathrm{dm}^{-3} \mathrm{Mg}$ and $27 \mathrm{mg} \mathrm{dm}^{-3} \mathrm{Cl}$ ) mixed with Hydrocomplex fertilizer (Yara International ASA, Oslo, Norway) containing $12 \% \mathrm{~N}, 11 \% \mathrm{P}_{2} \mathrm{O}_{5}, 18 \%$ $\mathrm{K}_{2} \mathrm{O}, 2.7 \% \mathrm{MgO}, 8 \% \mathrm{~S}, 0.015 \% \mathrm{~B}, 0.2 \% \mathrm{Fe}, 0.02 \% \mathrm{Mn}$, and $0.02 \% \mathrm{Zn}$ at a dose of $3 \mathrm{~g} \mathrm{dm}^{-3}$. The pots were placed in $60 \times 40 \times 19 \mathrm{~cm}$ plastic boxes, six pots per box, which were placed in a tunnel on white non-woven fabric. The air temperature was regulated with air vents, which opened automatically when the temperature exceeded $22^{\circ} \mathrm{C}$. The average monthly maximum/minimum air temperature and average relative humidity (RH) in the plastic house were respectively: April $22.7^{\circ} \mathrm{C} / 6.8^{\circ} \mathrm{C}, 70.9 \%$ $\mathrm{RH}$; May $25.0^{\circ} \mathrm{C} / 6.9{ }^{\circ} \mathrm{C}, 76.9 \% \mathrm{RH}$; June $27.3^{\circ} \mathrm{C} / 13.3^{\circ} \mathrm{C}, 70.6 \% \mathrm{RH}$; July $32.5^{\circ} \mathrm{C} / 17.6{ }^{\circ} \mathrm{C}, 69.4 \% \mathrm{RH}$; August $25.6^{\circ} \mathrm{C} / 14.7^{\circ} \mathrm{C}, 78.5 \% \mathrm{RH}$; September $25.9^{\circ} \mathrm{C} / 13.0^{\circ} \mathrm{C}, 80.4 \% \mathrm{RH}$; October $18.6^{\circ} \mathrm{C} / 7.1{ }^{\circ} \mathrm{C}, 90.2 \%$ $\mathrm{RH}$; and November $14.9^{\circ} \mathrm{C} / 5.5^{\circ} \mathrm{C}, 95.7 \% \mathrm{RH}$. The plants were cultivated until 15 November under natural day/night conditions (without shade nets or artificial lighting). The photosynthetic photon flux density (PPFD) in the plastic house on a sunny day ranged from 420 to $1151 \mu \mathrm{mol} \mathrm{m}^{-2} \mathrm{~s}^{-1}$ (as per Radiometer-Fotometr RF-100, Sonopan, Białystok, Poland). 


\subsection{Experimental Design}

On the 70th and 77th day after planting we used two growth regulators from Sigma-Aldrich Chemie GmbH (Schnelldorf, Germany): gibberellic acid (GA 3 ) at 50, 100, and $200 \mathrm{mg} \mathrm{dm}^{-3}$, and methyl jasmonate (MeJA) at 100, 500, and $1000 \mu \mathrm{mol} \mathrm{dm}{ }^{-3}$. The plants were sprayed in the afternoon with an aqueous solution of $\mathrm{GA}_{3}$ or MeJA, using about $15 \mathrm{~cm}^{3}$ solution per plant. The control plants were sprayed with distilled water. Ethanol $(0.04 \%, v / v)$ was used as a solvent. Directly after spraying, a plastic bag was placed on each plant and removed after two hours. Each experimental variant included 18 plants, six plants per repetition, in a random block system (Figure 2).

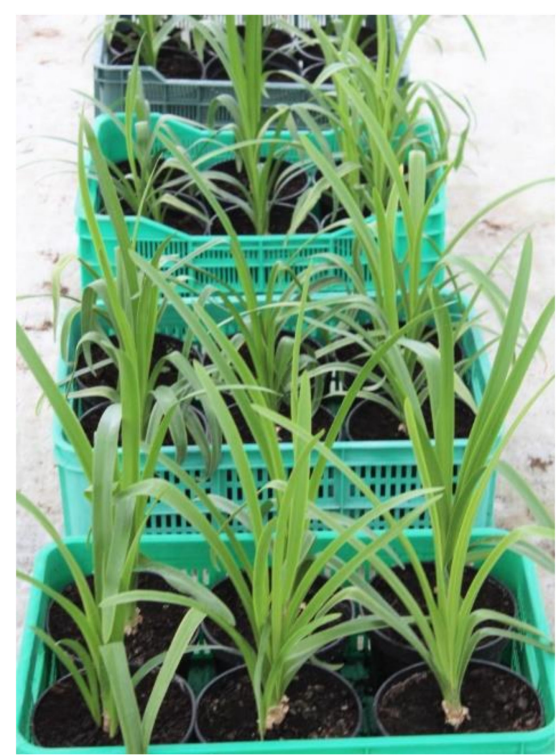

Figure 2. $\times$ A. tubergenii "Zwanenburg" plants on the 70th day after planting.

\subsection{Determination of Plant Growth Parameters}

The number of days from bulb planting to the beginning of anthesis was recorded when the first florets in the inflorescence opened. In this phase, we determined the stem length, leaf number, and length and width of the longest leaf. The flowering bulb number (\%) was determined in relation to the bulb number planted. When the inflorescences were fully developed, we counted the florets in each. Once the cultivation was complete, we removed the plants from the pots and determined the bulb fresh weight and the daughter bulb number per single planted bulb.

\subsection{Determination of Gas Exchange Rate, Chlorophyll Fluorescence, and Leaf Relative Chlorophyll Content}

The parameters of the gas exchange rate, including $\mathrm{CO}_{2}$ assimilation intensity (A), transpiration (E), stomatal conductance for water $\left(\mathrm{g}_{\mathrm{s}}\right)$, and $\mathrm{CO}_{2}$ concentration in the intercellular spaces of the assimilatory parenchyma $\left(\mathrm{c}_{\mathrm{i}}\right)$ were measured with a TPS-2 (PP Systems) portable gas analyzer (with standard settings), equipped with a PLC4 measuring chamber operating in an open system. Based on $\mathrm{CO}_{2}$ assimilation intensity and transpiration, the photosynthetic water-use efficiency $\left(\omega_{\mathrm{W}}\right)$ was calculated as a ratio of assimilation intensity to transpiration [32].

Chlorophyll fluorescence parameters were recorded using a Handy PEA (Hansatech) spectrofluorometer, based on the standard apparatus procedure. Leaves were shaded for $20 \mathrm{~min}$ prior to the measurement with a leaf clip (4 $\mathrm{mm}$ in diameter). The following parameters of chlorophyll fluorescence induction were measured and calculated using the spectrofluorometer: initial fluorescence excitation energy loss index in power antennas $\left(\mathrm{F}_{0}\right)$; maximum fluorescence after reduction of acceptors in photosystem II (PSII) and after dark adaptation $\left(\mathrm{F}_{\mathrm{M}}\right)$; variable fluorescence, determined after dark adaptation, a parameter dependent on the maximum quantum yield of PSII $\left(F_{V}=F_{M}-F_{0}\right)$; maximum potential photochemical reaction efficiency in PSII determined after dark adaptation and after reduction 
of acceptors in PS II $\left(\mathrm{F}_{\mathrm{V}} / \mathrm{F}_{\mathrm{M}}\right)$; PSII vitality index for the overall viability of this system (P I); the surface area above the chlorophyll fluorescence curve and between the $\mathrm{F}_{0}$ and $\mathrm{F}_{\mathrm{M}}$ points proportional to the size of the reduced plastoquinone acceptors in PS II (Area) [33].

Leaf relative chlorophyll content (greenness index) on the Soil and Plant Analysis Development (SPAD) scale was measured with the Chlorophyll Meter SPAD 502 (Konica-Minolta cooperation, Ltd., Osaka, Japan).

Non-destructive measurements of the gas exchange rate, chlorophyll fluorescence, and SPAD were carried out on the 91st cultivation day from 09:00 AM to 12:00 PM in the middle part of the adaxial leaf blades. The measurements involved two fully expanded leaves with a length of $48-50 \mathrm{~cm}$ and width of $2.0-2.2 \mathrm{~cm}$ in two matched for size plants from each repetition. The conditions in the tunnel during the analyses were: temperature $20-22{ }^{\circ} \mathrm{C}$, relative air humidity $70-75 \%$, natural light (PPFD $450 \mu \mathrm{mol} \mathrm{m}^{-2} \mathrm{~s}^{-1}$ ), air $\mathrm{CO}_{2}$ concentration $600 \mu \mathrm{mol} \mathrm{mol}^{-1}$.

\subsection{Determination of Total Sugars and Total Protein Content in Bulbs}

Once the cultivation was complete, four bulbs from each experimental variant were cleaned from the covering scales and roots. The analyses involved bulbs of similar fresh weight. The bulbs were cut longitudinally into four segments with a knife, and then middle scales were cut out from each segment and analyzed. Samples (250-300 g) were taken for the determination of total sugars and total protein. Concentrations of both reducing and invert sugars were determined by extraction with diluted ethanol, clarification of extracts with Carrez solutions, and titration with sodium thiosulphate solution in the presence of Luff-Schoorl reagent according to PN-R-64784:1994 standard. Total protein content was calculated based on nitrogen content determination according to the Kjeldahl method using a mineralization block, copper catalyst, and steam distillation into boric acid according to PN-EN ISO 5983-2:2009 standard. Content determination of the tested components was performed in three repetitions and presented as a percentage of fresh weight.

\subsection{Data Analysis}

The experimental results were statistically analyzed with the one-way ANOVA using Statistica 13.3 (TIBCO Software Inc. Statsoft, Kraków, Poland). To ensure the normality of data distribution, the plant flowering percentages were subjected to the Bliss transformation $(\arcsin (\operatorname{sqrt}(\mathrm{X}))$ and the analysis of variance. The confidence intervals were calculated based on Tukey's HSD test $(p \leq 0.05)$.

\section{Results}

\subsection{Effects of Foliar Application of $G A_{3}$ and MeJA Solutions on Growth, Flowering, and Bulb Yield}

Treatments with exogenous PGRs significantly affected the leaf number and their length, but not the stem length and floret number per inflorescence (Table 1). Plants treated with $\mathrm{GA}_{3}$ at all applied concentrations and MeJA at 500 and $1000 \mu \mathrm{mol} \mathrm{dm}{ }^{-3}$ formed significantly more leaves as compared with the control. The plants sprayed with $\mathrm{GA}_{3}$ at $200 \mathrm{mg} \mathrm{dm}^{-3}$ produced the greatest leaf number, which were also the longest.

In all cases, one bulb produced only one inflorescence. Anthesis time and bulb flowering percentage depended on the phytohormone type and concentration (Table 2). Plants treated with 100 and $200 \mathrm{mg} \mathrm{dm}^{-3} \mathrm{GA}_{3}$ were the first to start anthesis, while those sprayed with 50 and $100 \mathrm{mg} \mathrm{dm}^{-3}$ $\mathrm{GA}_{3}$ showed the greatest flowering percentage. MeJA treatment delayed flowering and significantly reduced the flowering plant number, regardless of the concentration applied.

PGR treatments and their concentrations influenced bulb yield (Table 3). Spraying with $\mathrm{GA}_{3}$ solutions at all tested concentrations and MeJA at $1000 \mu \mathrm{mol} \mathrm{dm}{ }^{-3}$ significantly increased the fresh bulb weight as compared with the control plants. Plants treated with 100 and $200 \mathrm{mg} \mathrm{dm}^{-3} \mathrm{GA}_{3}$ exhibited the greatest fresh bulb weight. Greater PGR concentrations $\left(\mathrm{GA}_{3}\right.$ at 100 and $200 \mathrm{mg} \mathrm{dm}^{-3}$; 
MeJA at 500 and $1000 \mu \mathrm{mol} \mathrm{dm}{ }^{-3}$ ) significantly increased the daughter bulb number in comparison with untreated plants.

Table 1. Effects of $\mathrm{GA}_{3}$ and MeJA on morphological traits of $\times$ Amarine tubergenii "Zwanenburg" at the beginning of anthesis.

\begin{tabular}{cccccc}
\hline & Treatment & Leaves (no.) & Leaf Length (cm) & Stem Length (cm) & Florets (no.) \\
\hline \multirow{2}{*}{$\mathrm{GA}_{3}$} & Control & $9.00 \pm 0.50^{\mathrm{d}, *}$ & $49.9 \pm 1.49^{\mathrm{bc}}$ & $72.5 \pm 4.39^{\mathrm{a}}$ & $7.97 \pm 0.64^{\mathrm{a}}$ \\
& $50 \mathrm{mg} \mathrm{dm}^{-3}$ & $11.2 \pm 0.76^{\mathrm{bc}}$ & $51.8 \pm 1.07^{\mathrm{bc}}$ & $72.5 \pm 0.95^{\mathrm{a}}$ & $8.33 \pm 0.76^{\mathrm{a}}$ \\
& $100 \mathrm{mg} \mathrm{dm}^{-3}$ & $12.3 \pm 0.25^{\mathrm{ba}}$ & $53.8 \pm 1.97^{\mathrm{b}}$ & $74.0 \pm 4.52^{\mathrm{a}}$ & $8.33 \pm 0.76^{\mathrm{a}}$ \\
\multirow{2}{*}{$\mathrm{MeJA}$} & $200 \mathrm{mg} \mathrm{dm}^{-3}$ & $12.8 \pm 0.29^{\mathrm{a}}$ & $58.1 \pm 2.28^{\mathrm{a}}$ & $75.6 \pm 4.15^{\mathrm{a}}$ & $7.97 \pm 0.64^{\mathrm{a}}$ \\
& $100 \mu \mathrm{mol} \mathrm{dm}^{-3}$ & $9.00 \pm 0.50^{\mathrm{d}}$ & $49.1 \pm 1.50^{\mathrm{c}}$ & $72.3 \pm 2.78^{\mathrm{a}}$ & $7.87 \pm 0.15^{\mathrm{a}}$ \\
& $500 \mu \mathrm{mol} \mathrm{dm}^{-3}$ & $10.5 \pm 0.50^{\mathrm{c}}$ & $51.1 \pm 0.75^{\mathrm{bc}}$ & $71.6 \pm 3.45^{\mathrm{a}}$ & $7.58 \pm 0.38^{\mathrm{a}}$ \\
& $1000 \mu \mathrm{mol} \mathrm{dm}^{-3}$ & $11.5 \pm 0.50^{\mathrm{abc}}$ & $50.4 \pm 0.80^{\mathrm{bc}}$ & $73.5 \pm 4.20^{\mathrm{a}}$ & $7.50 \pm 0.43^{\mathrm{a}}$ \\
\hline
\end{tabular}

* Means over each column not marked with the same letter are significantly different at $p \leq 0.05$. Data are expressed as mean and standard deviation $( \pm \mathrm{SD})$.

Table 2. Effects of $\mathrm{GA}_{3}$ and MeJA on anthesis time and the bulb flowering percentage of $\times$ Amarine tubergenii "Zwanenburg".

\begin{tabular}{cccc}
\hline & Treatment & Time to Anthesis (d) & Bulbs Flowering (\%) \\
\hline \multirow{3}{*}{ GA $_{3}$} & Control & $188 \pm 1.00^{\mathrm{b} *}$ & $46.5 \pm 8.85^{\mathrm{bc}}$ \\
& $50 \mathrm{mg} \mathrm{dm}^{-3}$ & $185 \pm 2.65^{\mathrm{bc}}$ & $82.2 \pm 16.3^{\mathrm{a}}$ \\
& $100 \mathrm{mg} \mathrm{dm}^{-3}$ & $177 \pm 2.65^{\mathrm{c}}$ & $82.2 \pm 16.3^{\mathrm{a}}$ \\
\multirow{3}{*}{ MeJA } & $200 \mathrm{mg} \mathrm{dm}^{-3}$ & $176 \pm 1.00^{\mathrm{c}}$ & $65.6 \pm 4.21^{\mathrm{ab}}$ \\
& $100 \mu \mathrm{mol} \mathrm{dm}^{-3}$ & $206 \pm 5.51^{\mathrm{a}}$ & $30.4 \pm 6.66^{\mathrm{c}}$ \\
& $500 \mu \mathrm{mol} \mathrm{dm}^{-3}$ & $206 \pm 5.03^{\mathrm{a}}$ & $22.8 \pm 8.28^{\mathrm{c}}$ \\
& $1000 \mu \mathrm{mol} \mathrm{dm}^{-3}$ & $203 \pm 5.86^{\mathrm{a}}$ & $28.0 \pm 7.68^{\mathrm{c}}$ \\
\hline
\end{tabular}

* Means over each column not marked with the same letter are significantly different at $p \leq 0.05$. Data are expressed as mean and standard deviation $( \pm \mathrm{SD})$.

Table 3. Effects of $\mathrm{GA}_{3}$ and MeJA on $\times$ Amarine tubergenii "Zwanenburg" bulb yield.

\begin{tabular}{cccc}
\hline & Treatment & Bulb Weight (g) & Daughter Bulbs (no.) \\
\hline \multirow{3}{*}{$\mathrm{GA}_{3}$} & Control & $97.7 \pm 1.46^{\mathrm{c*}}$ & $1.28 \pm 0.03^{\mathrm{b}}$ \\
& $50 \mathrm{mg} \mathrm{dm}^{-3}$ & $107 \pm 3.61^{\mathrm{b}}$ & $1.78 \pm 0.20^{\mathrm{ab}}$ \\
& $100 \mathrm{mg} \mathrm{dm}^{-3}$ & $128 \pm 5.51^{\mathrm{a}}$ & $2.16 \pm 0.15^{\mathrm{a}}$ \\
\multirow{3}{*}{ MeJA } & $200 \mathrm{mg} \mathrm{dm}^{-3}$ & $134 \pm 4.26^{\mathrm{a}}$ & $2.30 \pm 0.30^{\mathrm{a}}$ \\
& $100 \mu \mathrm{mol} \mathrm{dm}^{-3}$ & $99.1 \pm 2.80^{\mathrm{c}}$ & $1.35 \pm 0.13^{\mathrm{b}}$ \\
& $500 \mu \mathrm{mol} \mathrm{dm}^{-3}$ & $100 \pm 3.61^{\mathrm{c}}$ & $2.27 \pm 0.25^{\mathrm{a}}$ \\
& $1000 \mu \mathrm{mol} \mathrm{dm}^{-3}$ & $112 \pm 4.63^{\mathrm{b}}$ & $2.27 \pm 0.25^{\mathrm{a}}$ \\
\hline
\end{tabular}

* Means over each column not marked with the same letter are significantly different at $p \leq 0.05$. Data are expressed as mean and standard deviation $( \pm \mathrm{SD})$.

\subsection{Effects of Foliar Application of $G A_{3}$ and MeJA Solutions on Gas Exchange Rate}

Table 4 presents the data on leaf gas exchange parameters depending on the plant hormone and its concentration. The greatest $\mathrm{CO}_{2}$ assimilation intensity (A) was found in plants sprayed with 200 $m g \mathrm{dm}^{-3} \mathrm{GA}_{3}$ solution. This parameter in the other variants did not differ significantly from the control. $\mathrm{GA}_{3}$ or MeJA application resulted in a significant increase in the intensity of transpiration (E), as compared with untreated plants, except for $1000 \mu \mathrm{mol} \mathrm{dm}{ }^{-3} \mathrm{MeJA}$. The greatest $\mathrm{E}$ was recorded in plants sprayed with $100 \mu \mathrm{mol} \mathrm{dm}{ }^{-3}$ MeJA. The increase was more than twofold vs. the control. Plants treated with $50 \mathrm{mg} \mathrm{dm}^{-3} \mathrm{GA}_{3}$ exhibited the greatest photosynthetic water-use efficiency $\left(\omega_{\mathrm{W}}\right)$. The $\omega_{\mathrm{W}}$ for the other treatments did not differ significantly from the control. Exogenous application of $\mathrm{GA}_{3}$ and MeJA at all tested concentrations resulted in a significant increase in water stomatal conductance 
$\left(g_{S}\right)$. Compared to untreated plants, the greatest, more than fourfold increase in $g_{S}$ was recorded after the application of 100 and $500 \mu \mathrm{mol} \mathrm{dm}{ }^{-3} \mathrm{MeJA}$. Both phytohormones triggered a significant increase in $\mathrm{CO}_{2}$ concentration in the intercellular spaces $\left(c_{i}\right)$, particularly noticeable in the plants treated with $1000 \mu \mathrm{mol} \mathrm{dm}{ }^{-3} \mathrm{MeJA}$.

Table 4. Effects of $\mathrm{GA}_{3}$ and MeJA on $\mathrm{CO}_{2}$ assimilation intensity (A), transpiration (E), photosynthetic water-use efficiency $\left(\omega_{\mathrm{W}}\right)$, stomatal conductance $\left(\mathrm{g}_{\mathrm{s}}\right)$, and $\mathrm{CO}_{2}$ concentration $\left(\mathrm{c}_{\mathrm{i}}\right)$ of $\times$ A. tubergenii "Zwanenburg".

\begin{tabular}{|c|c|c|c|c|c|c|}
\hline & Treatment & $\frac{A}{\left(\mu \mathrm{mol} \mathrm{m} \mathrm{m}^{-2} \mathrm{~s}^{-1}\right)}$ & $\begin{array}{c}E \\
\left(\mathrm{mmol} \mathrm{m} \mathrm{m}^{-2} \mathrm{~s}^{-1}\right)\end{array}$ & $\begin{array}{c}\omega_{W} \\
\left(\mathrm{mmol} \mathrm{mol}^{-1}\right)\end{array}$ & $\underset{\left(\mathrm{mol} \mathrm{m} \mathrm{m}^{-2} \mathrm{~s}^{-1}\right)}{\mathrm{g}_{\mathrm{s}}}$ & $\begin{array}{c}\mathrm{c}_{\mathrm{i}} \\
\left(\mu \mathrm{mol} \mathrm{mol}^{-1}\right)\end{array}$ \\
\hline \multirow{3}{*}{$\mathrm{GA}_{3}$} & Control & $6.67 \pm 0.41 \mathrm{bc} *$ & $0.82 \pm 0.21^{\mathrm{d}}$ & $4.67 \pm 1.14^{b c}$ & $0.10 \pm 0.02^{\mathrm{d}}$ & $409 \pm 40.3^{c}$ \\
\hline & $50 \mathrm{mg} \mathrm{dm}^{-3}$ & $7.40 \pm 0.60 \mathrm{bc}$ & $1.49 \pm 0.12^{b c}$ & $6.99 \pm 0.60^{\mathrm{a}}$ & $0.28 \pm 0.03^{b}$ & $449 \pm 4.12^{b}$ \\
\hline & $100 \mathrm{mg} \mathrm{dm}^{-3}$ & $7.75 \pm 0.65^{a b}$ & $1.41 \pm 0.26^{c}$ & $5.75 \pm 0.98^{a b}$ & $0.31 \pm 0.07^{b}$ & $455 \pm 9.66^{\mathrm{ab}}$ \\
\hline \multirow{4}{*}{ MeJA } & $200 \mathrm{mg} \mathrm{dm}^{-3}$ & $8.99 \pm 0.84^{a}$ & $1.44 \pm 0.15^{c}$ & $5.40 \pm 0.65^{b c}$ & $0.34 \pm 0.07^{b}$ & $470 \pm 9.35^{\mathrm{ab}}$ \\
\hline & $100 \mu \mathrm{mol} \mathrm{dm}{ }^{-3}$ & $6.32 \pm 0.27^{c}$ & $1.75 \pm 0.09^{\mathrm{a}}$ & $4.32 \pm 0.21^{c}$ & $0.43 \pm 0.05^{a}$ & $444 \pm 6.00^{b}$ \\
\hline & $500 \mu \mathrm{mol} \mathrm{dm}-3$ & $6.16 \pm 0.52^{c}$ & $1.72 \pm 0.07^{a b}$ & $4.16 \pm 0.40^{c}$ & $0.44 \pm 0.04^{\mathrm{a}}$ & $468 \pm 6.57^{a b}$ \\
\hline & $1000 \mu \mathrm{mol} \mathrm{dm}{ }^{-3}$ & $7.10 \pm 0.77^{b c}$ & $1.05 \pm 0.14^{\mathrm{d}}$ & $5.10 \pm 1.48^{b c}$ & $0.21 \pm 0.04^{c}$ & $482 \pm 21.1^{a}$ \\
\hline
\end{tabular}

* Means over each column not marked with the same letter are significantly different at $p \leq 0.05$. Data are expressed as mean and standard deviation $( \pm S D)$.

\subsection{Effects of Foliar Application of $\mathrm{GA}_{3}$ and MeJA Solutions on Chlorophyll Fluorescence and SPAD}

In comparison with the control plants, $\mathrm{GA}_{3}$ and MeJA did not significantly affect the chlorophyll fluorescence parameters $\left(\mathrm{F}_{\mathrm{V}} / \mathrm{F}_{\mathrm{M}}, \mathrm{PI}\right.$, and Area), but caused changes in the leaf greenness (SPAD index) (Table 5). Plants treated with $200 \mathrm{mg} \mathrm{dm}^{-3} \mathrm{GA}_{3}$ showed the greatest SPAD values. Similarly, an increased greenness index was observed in plants treated with 50 and $100 \mathrm{mg} \mathrm{dm}^{-3} \mathrm{GA}_{3}$ and 1000 $\mu \mathrm{mol} \mathrm{dm}{ }^{-3}$ MeJA.

Table 5. Effects of $\mathrm{GA}_{3}$ and MeJA on chlorophyll fluorescence parameters ( $\mathrm{F}_{\mathrm{V}} / \mathrm{F}_{\mathrm{M}}$, PI, Area) and leaf greenness index (SPAD) in $\times$ A. tubergenii "Zwanenburg" leaves.

\begin{tabular}{cccccc}
\hline & Treatment & $\mathbf{F}_{\mathbf{V}} / \mathbf{F}_{\mathbf{M}}$ & PI & Area & SPAD \\
\hline \multirow{3}{*}{$\mathrm{GA}_{3}$} & Control & $0.79 \pm 0.03^{\mathrm{ab} *}$ & $1.72 \pm 0.39^{\mathrm{ab}}$ & $49,428 \pm 8097^{\mathrm{ab}}$ & $52.2 \pm 1.40^{\mathrm{c}}$ \\
& $50 \mathrm{mg} \mathrm{dm}^{-3}$ & $0.77 \pm 0.03^{\mathrm{ab}}$ & $1.71 \pm 0.30^{\mathrm{ab}}$ & $40,656 \pm 6448^{\mathrm{b}}$ & $56.9 \pm 0.67^{\mathrm{b}}$ \\
& $100 \mathrm{mg} \mathrm{dm}^{-3}$ & $0.78 \pm 0.02^{\mathrm{ab}}$ & $1.66 \pm 0.18^{\mathrm{b}}$ & $47,401 \pm 7553^{\mathrm{ab}}$ & $58.5 \pm 1.35^{\mathrm{b}}$ \\
\multirow{2}{*}{ MeJA } & $200 \mathrm{mg} \mathrm{dm}^{-3}$ & $0.82 \pm 0.04^{\mathrm{a}}$ & $2.02 \pm 0.20^{\mathrm{a}}$ & $59,420 \pm 13,999^{\mathrm{a}}$ & $66.0 \pm 2.48^{\mathrm{a}}$ \\
& $100 \mu \mathrm{mol} \mathrm{dm}^{-3}$ & $0.77 \pm 0.05^{\mathrm{ab}}$ & $1.73 \pm 0.08^{\mathrm{ab}}$ & $41,702 \pm 6330^{\mathrm{b}}$ & $51.8 \pm 0.40^{\mathrm{c}}$ \\
& $500 \mu \mathrm{mol} \mathrm{dm}^{-3}$ & $0.73 \pm 0.04^{\mathrm{b}}$ & $1.66 \pm 0.06^{\mathrm{b}}$ & $47,593 \pm 7939^{\mathrm{ab}}$ & $55.0 \pm 1.50^{\mathrm{bc}}$ \\
& $1000 \mu \mathrm{mol} \mathrm{dm}^{-3}$ & $0.76 \pm 0.05^{\mathrm{ab}}$ & $1.76 \pm 0.12^{\mathrm{ab}}$ & $37,339 \pm 14,819^{\mathrm{b}}$ & $59.5 \pm 2.35^{\mathrm{b}}$ \\
\hline
\end{tabular}

${ }^{*}$ Means over each column not marked with the same letter are significantly different at $p \leq 0.05$. Data are expressed as mean and standard deviation $( \pm \mathrm{SD})$.

\subsection{Effects of Foliar Application of $\mathrm{GA}_{3}$ and MeJA Solutions on Total Sugars and Total Protein Content}

$\mathrm{GA}_{3}$ and MeJA application significantly increased bulb total sugar content (Figure 3a) at all concentrations. The greatest total sugars content was found in plants treated with 100 and $200 \mathrm{mg}$ $\mathrm{dm}^{-3} \mathrm{GA}_{3}$ and $1000 \mu \mathrm{mol} \mathrm{dm}{ }^{-3} \mathrm{MeJA} . \mathrm{GA}_{3}$ and MeJA at the greatest concentrations also increased the bulb total protein content (Figure $3 b$ ). 
(a)

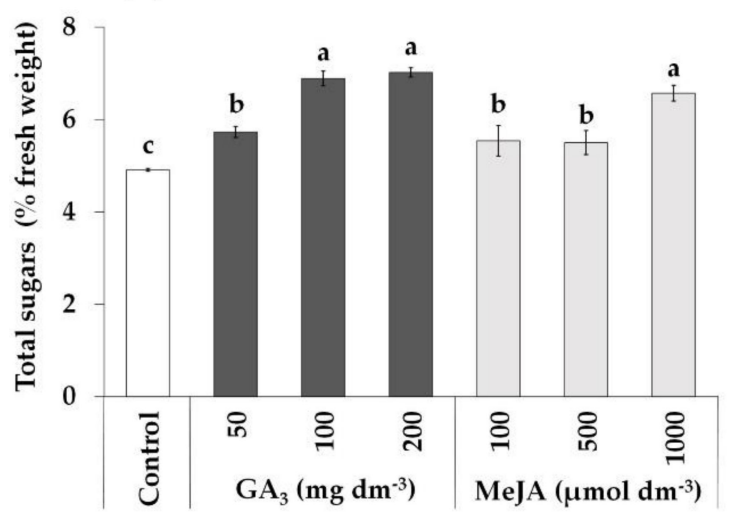

(b)

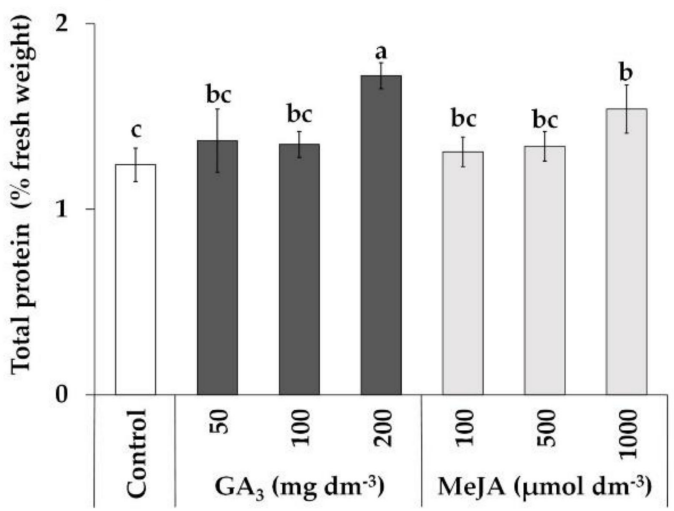

Figure 3. Effects of foliar application of $\mathrm{GA}_{3}$ and MeJA solutions on total sugar (a) and total protein (b) content in the bulbs of $\times$ A. tubergenii "Zwanenburg". Data are mean $\pm \mathrm{SD}(\mathrm{n}=3)$. Different letters above the error bars indicate significant differences for $p<0.05$.

\section{Discussion}

\subsection{Effect of $\mathrm{GA}_{3}$ and MeJA on Growth, Flowering, and Bulb Yield}

To improve ornamental geophyte quality, various plant growth and development regulators are used in horticultural practice [34,35]. $\times$ Amarine tubergenii "Zwanenburg" treated with $\mathrm{GA}_{3}$ (50, 100, and $200 \mathrm{mg} \mathrm{dm}^{-3}$ ) and MeJA (500 and $1000 \mu \mathrm{mol} \mathrm{dm}^{-3}$ ) exhibited a significantly increased leaf number (Table 1). Moreover, at the greatest $\mathrm{GA}_{3}$ concentration, the leaves were much longer. More leaves after $\mathrm{GA}_{3}$ application were observed by Ramzan et al. [36] in Tulipa gesneriana L. The activity of gibberellin family growth regulators involves the stimulation of plant cell mitotic division [37], which can lead to intense growth and production of more leaves. Diallo et al. [38] showed a stimulating effect of MeJA on leaf count in Triticum aestivum L. The researchers suggested that the beneficial effect of MeJA on the leaf count may be because MeJA maintained plants in the vegetative phase longer, so that plants continued their intense growth instead of proceeding to the generative phase. Similarly, we showed MeJA treatment delayed anthesis time (Table 2).

Neither of the phytohormones used in this study affected the inflorescence morphology, including the floret number (Table 1). The lack of PGR effects on the floret number may stem from the fact that both phytohormones were applied after the inflorescence initiation inside of the bulb. In Nerine bowdenii the time between flower primordia initiation and anthesis is 2-3 years, and in Amaryllis belladonna over a year $[6,10]$.

Foliar treatment with both $\mathrm{GA}_{3}$ and MeJA strongly influenced the anthesis time and the flowering percentage, but $\mathrm{GA}_{3}$ worked differently than MeJA (Table 2). The plants sprayed with $\mathrm{GA}_{3}$ at 100 and $200 \mathrm{mg} \mathrm{dm}^{-3}$ began anthesis faster. Earlier flowering following $\mathrm{GA}_{3}$ application at 150-300 ppm was also observed in A. belladonna [39]. However, in Nerine flexuosa $\mathrm{GA}_{3}$ bulb-dip treatment at 100 $\mathrm{mg} / \mathrm{L}$ did not accelerate flowering [40]. In Nerine, many inflorescences did not elongate and became desiccated, thus no flowering occurred [41]. It may be assumed that in $\times A$. tubergenii "Zwanenburg" $\mathrm{GA}_{3}$ stimulates the final stages of stem elongation and anthesis. $\mathrm{GA}_{3}$ treatment at 50 and $100 \mathrm{mg} \mathrm{dm}^{-3}$ not only accelerated anthesis, but also positively affected the inflorescence yield by increasing the bulb flowering percentage (Table 2). The increased number of $\times A$. tubergenii "Zwanenburg" flowering plants following $\mathrm{GA}_{3}$ treatment is probably because of the faster execution of the flowering phase. Our results are highly practical, as $\mathrm{GA}_{3}$ makes more plants flower at an earlier stage, which allows for harvesting the inflorescences of field or unheated tunnel-grown plants before the autumn frosts.

MeJA, regardless of its concentration, delayed flowering and decreased the number of flowering $\times A$. tubergenii "Zwanenburg" plants (Table 2). Similarly, Zhai et al. [42] reported an inhibitory effect of jasmonic acid on Arabidopsis thaliana flowering. Maciejewska and Kopcewicz [28] observed that 
treatment with MeJA reduced the flower bud number in Pharbitis nil (L.) Roth. Conversely, $50 \mu \mathrm{M}$ MeJA application in Brassica napus L. moved the flowering time forward and increased the flower number [29]. Jasmonates control individual plant ontogenesis phases, but their exact mode of action in the regulation of growth and flowering induction is not known.

A common problem in bulbous plant propagation is their low propagation rate, which can be increased using PGRs [43]. Bulb yield analysis in $\times A$. tubergenii "Zwanenburg" clearly showed that $\mathrm{GA}_{3}$ increases the bulb weight and daughter bulb number (Table 3). In Allium karataviense Regel GA 3 spraying increased the bulb weight and total bulb yield [44]. Allium sativum L. treatment with $\mathrm{GA}_{3}$ positively affected axillary bud formation, clove number per bulb, bulb weight, and bulb volume [45]. The stimulating effect of $\mathrm{GA}_{3}$ on bulbing may be because gibberellins enhance gene expression correlated with cell elongation necessary for cell development and differentiation, and induced lateral bud formation [46].

MeJA at concentrations of 500 and $1000 \mu \mathrm{mol} \mathrm{dm}{ }^{-3}$ had a similarly stimulating effect on the propagation rate as $\mathrm{GA}_{3}$ application. Moreover, bulbs obtained from plants treated with the greatest MeJA dose displayed significantly greater weight (Table 3). In vitro jasmonates application increased the bulb number and improved bulblet quality parameters in A. sativum [47] and Narcissus triandrus L. [48]. Nojiri et al. [49] postulated that both jasmonic acid and MeJA are bulbing hormones, as they both stimulate bulbing through microtubles disruption.

\subsection{Effect of $\mathrm{GA}_{3}$ and MeJA on Physiological Parameters}

Numerous studies have shown that the course and intensity of the most important plant physiological processes can be regulated with exogenous growth regulators [50,51]. In our study, $\mathrm{GA}_{3}$ regardless of its concentration enhanced transpiration, stomatal conductance for water, $\mathrm{CO}_{2}$ concentration in the intercellular spaces of the assimilatory parenchyma, and SPAD in $\times A$. tubergenii "Zwanenburg" (Tables 4 and 5). A significant increase in $\mathrm{CO}_{2}$ assimilation intensity was found only in plants sprayed with $\mathrm{GA}_{3}$ solution at $200 \mathrm{mg} \mathrm{dm}^{-3}$. These plant leaves showed the greatest chlorophyll fluorescence and SPAD index values. It can be assumed that as a result of increased photosynthesis, plants treated with $\mathrm{GA}_{3}$ in the greatest dose produced the greatest leaf number and daughter bulbs, and had the longest leaves and bulbs with the greatest fresh weight. Increased photosynthetic efficiency results in faster vegetative growth and leads to increased biomass production [52].

MeJA applied in all tested concentrations increased the stomatal conductance and leaf $\mathrm{CO}_{2}$ concentration without affecting $\mathrm{CO}_{2}$ assimilation intensity and assessed fluorescence parameters (Table 4). Moreover, MeJA application at 100 and $500 \mu \mathrm{mol} \mathrm{dm}{ }^{-3}$ increased transpiration, and at $1000 \mathrm{dm}^{-3}$ enhanced leaf greenness (SPAD; Table 5). Our results partially confirm those of Ahmadi et al. [53], who found that spraying B. napus with $100 \mu \mathrm{M}$ MeJA significantly increased the $\mathrm{CO}_{2}$ compensation point and respiration rate. A positive effect of MeJA on photosynthetic parameters was observed in two Prunus dulcis Mill. rootstocks [54]. The effect of exogenous MeJA on the plant photosynthetic apparatus is complex and depends on many factors, including species, concentration, and environmental conditions $[21,23,25]$.

Geophytes accumulate reserve substances in their bulbs that determine the correct course of dormancy, growth, and flowering [55]. Both PGRs significantly increased total sugar content in $\times A$. tubergenii "Zwanenburg" bulbs, especially when applied at 100 and $200 \mathrm{mg} \mathrm{dm}^{-3}\left(\mathrm{GA}_{3}\right)$ and $1000 \mu \mathrm{mol}$ $\mathrm{dm}^{-3}$ (MeJA) (Figure 3a). Moreover, bulbs obtained from plants treated with $\mathrm{GA}_{3}$ or MeJA in the greatest concentrations featured significantly more total protein (Figure 3b). Wakchaure et al. [56] found an increased total soluble sugar content and total protein content in Allium cepa L. bulbs treated with $\mathrm{GA}_{3}$. Jasmonates promote starch accumulation in tubers, as it was apparent in Solanum tuberosum L. subsp. tuberosum [57]. In $\times$ A. tubergenii "Zwanenburg", the greatest total sugars content and total bulb protein was found in plants sprayed with $\mathrm{GA}_{3}$ at $200 \mathrm{mg} \mathrm{dm}^{-3}$ (Figure 3). This could have been related to increased $\mathrm{CO}_{2}$ assimilation intensity, and as a result, better bulb supplementation with photosynthesis products. Plant bulbs treated with $\mathrm{GA}_{3}$ at the greatest dose showed the greatest fresh 
weight (Table 3). Most probably, increased bulb weight and a greater nutrient content, especially sugars, improves plant flowering in the subsequent growing season. In the case of $N$. bowdenii, the parent species of the nothogenus $\times$ Amarine, inflorescence quality and flowering percentage is related to bulb size and carbohydrate content in fleshy leaf bases and fleshy scales $[11,12]$. Decreased sugar level in bulbs during gynoecium development is implicated in inflorescence abortion [58]. Therefore, it seems advisable to conduct further research on the residual impact of PGRs on the growth and anthesis of $\times A$. tubergenii. We intend to observe bulb performance in the following year, and to dissect them to observe flower primordia and their development after external PGR application, and monitor how it affects floral initiation and development.

\section{Conclusions}

We examined the possibility of using PGRs in the cultivation of $\times$ A. tubergenii, an ornamental geophyte with great floricultural potential. Plant growth and physiological condition depended on the PGR type and its concentration. The influence of $\mathrm{GA}_{3}$ and MeJA on anthesis time was opposite, as $\mathrm{GA}_{3}$ accelerated and MeJA delayed the beginning of anthesis. Additionally, $\mathrm{GA}_{3}$ increased and MeJA decreased the bulb flowering percentage. All GA 3 concentrations and MeJA at 500 and $1000 \mu \mathrm{mol}$ $\mathrm{dm}^{-3}$ stimulated daughter bulb formation. Among all treatments, $\mathrm{GA}_{3}$ at $200 \mathrm{mg} \mathrm{dm}^{-3}$ seemed to most favorably affect the leaf number, their length, bulb weight, daughter bulb number, photosynthesis rate, greenness, total sugar, and total protein content in bulbs. This treatment could be used as a method for improving $\times$. tubergenii "Zwanenburg" plant growth, anthesis, and bulb yield in commercial production.

Author Contributions: Conceptualization, P.S.; methodology, P.S. and M.M.; software, P.S., M.M. and R.P.; formal analysis, P.S., M.M., A.Z. and P.P.; data curation, P.S., M.M., A.Z., R.P. and P.P., writing-original draft preparation, P.S.; writing-review and editing, M.M., A.Z., G.M., A.P. and Ł.Ł.; visualization, P.S. All authors have read and agreed to the published version of the manuscript.

Funding: This research received no external funding.

Acknowledgments: The authors would like to thank Christina Baker, for linguistic corrections of the manuscript.

Conflicts of Interest: The authors declare no conflict of interest.

\section{References}

1. Seaton, K.; Bettin, A.; Grüneberg, H. New ornamental plants for horticulture. In Horticulture: Plants for People and Places; Dixonand, G.R., Aldous, D.E., Eds.; Springer: Dordrecht, The Netherlands, 2014; pp. 435-463.

2. Kamenetsky, R.; Miller, W.B. The global trade in ornamental geophytes. Chron. Hortic. 2010, 50, 27-30.

3. Benschop, M.; Kamenetsky, R.; Nard, M.L.; Okubo, H.; De Hertogh, A. The Global flower bulb industry: Production, utilisation, research. Hortic. Rev. 2010, 36, 1-115.

4. Hadas, R.; Kamenetsky, R.; Fragman-Sapir, O. Ex-Situ conservation of Israel's native geophytes-Source for development of new ornamental crops. Isr. J. Plant Sci. 2009, 57, 277-285. [CrossRef]

5. Coertze, A.F.; Louw, E. The breeding of interspecies and intergenera hybrids in the Amaryllidaceae. Acta Hortic. 1990, 266, 349-352. [CrossRef]

6. Theron, K.I.; De Hertogh, A.A. Amaryllidaceae: Geophytic growth, development, and flowering. Hortic. Rev. 2001, 25, 1-70.

7. Cahlíková, L.; Vaněčková, N.; Šafratová, M.; Breiterová, K.; Blunden, G.; Hulcová, D.; Opletal, L. The Genus Nerine Herb. (Amaryllidaceae): Ethnobotany, Phytochemistry, and Biological Activity. Molecules 2019, $24,4238$. [CrossRef]

8. Duncan, G. Amaryllis magic: Feature. Veld Flora 2004, 90, 142-147.

9. Amarine Belladiva. Available online: https://www.florapodium.com/index.php/en/amarine-belladiva-en (accessed on 5 June 2020).

10. Theron, K.I.; Jacobs, G. Comparative growth and development of Nerine bowdenii W. Watson: Bulbs In Situ versus replanted. Hort. Sci. 1994, 29, 1493-1496. [CrossRef] 
11. Theron, K.I.; Jacobs, G. Inflorescence abortion in Nerine bowdenii W. Watts. Acta Hortic. 1992, 32, 97-104. [CrossRef]

12. Theron, K.I.; Jacobs, G. The effect of irradiance, defoliation, and bulb size on flowering of Nerine bowdenii W. Watson (Amaryllidaceae). J. Amer. Soc. Hort. Sci. 1996, 121, 115-122. [CrossRef]

13. Sajjad, Y.; Jaskani, M.J.; Asif, M.; Qasim, M. Application of plant growth regulators in ornamental plants: A review. Pak. J. Agric. Sci. 2017, 54. [CrossRef]

14. Salachna, P.; Zawadzińska, A. Effect of daminozide and flurprimidol on growth, flowering and bulb yield of Eucomis autumnalis (Mill.) Chitt. Folia Hortic. 2017, 29, 33-38. [CrossRef]

15. Saniewski, M.; Kawa-Miszczak, L.; Wegrzynowicz-Lesiak, E. Role of ABA, gibberellins and auxin in dormancy and dormancy release of tulip bulbs. In Dormancy in Plants: From Whole Plant Behaviour to Cellular Control; Viémont, J., Crabbé, J., Eds.; CAB International Publishing: New York, NY, USA, 2000; pp. 227-245.

16. Bonnet-Masimbert, M.; Zaerr, J.B. The role of plant growth regulators in promotion of flowering. J. Plant Growth Regul. 1987, 6, 13-35. [CrossRef]

17. Ionescu, I.A.; Møller, B.L.; Sánchez-Pérez, R. Chemical control of flowering time. J. Exp. Bot. 2017, 68, 369-382. [CrossRef]

18. Dos Santos, D.S.; Cardoso-Gustavson, P.; Nievola, C.C. Stem elongation of ornamental bromeliad in tissue culture depends on the temperature even in the presence of gibberellic acid. Acta Physiol. Plant. 2017, $39,230$. [CrossRef]

19. Francis, D.; Sorrell, D.A. The interface between the cell cycle and plant growth regulators: A mini review. J. Plant Growth Regul. 2001, 33, 1-12. [CrossRef]

20. Iftikhar, A.; Ali, S.; Yasmeen, T.; Arif, M.S.; Zubair, M.; Rizwan, M.; Alhaithloul, H.A.S.; Alayafi, A.A.M.; Soliman, M.H. Effect of gibberellic acid on growth, photosynthesis and antioxidant defense system of wheat under zinc oxide nanoparticle stress. Environ. Pollut. 2019, 254, 113109. [CrossRef]

21. Koo, A.J.; Howe, G.A. The wound hormone jasmonate. Phytochemistry 2009, 70, 1571-1580. [CrossRef]

22. Linkies, A.; Leubner-Metzger, G. Beyond gibberellins and abscisic acid: How ethylene and jasmonates control seed germination. Plant Cell Rep. 2012, 31, 253-270. [CrossRef]

23. Golovatskaya, I.F.; Karnachuk, R.A. Effect of jasmonic acid on morphogenesis and photosynthetic pigment level in Arabidopsis seedlings grown under green light. Russ. J. Plant Physiol. 2008, 55, 220-224. [CrossRef]

24. Reyes-Díaz, M.; Lobos, T.; Cardemil, L.; Nunes-Nesi, A.; Retamales, J.; Jaakola, L.; Alberdi, M.; Ribera-Fonseca, A. Methyl jasmonate: An alternative for improving the quality and health properties of fresh fruits. Molecules 2016, 21, 567. [CrossRef]

25. Ahmad, P.; Rasool, S.; Gul, A.; Sheikh, S.A.; Akram, N.A.; Ashraf, M.; Kazi, A.M.; Gucel, S. Jasmonates: Multifunctional roles in stress tolerance. Front. Plant Sci. 2016, 7, 813. [CrossRef] [PubMed]

26. Albrechtova, J.T.P.; Ullmann, J. Methyl jasmonate inhibits growth and flowering in Chenopodium rubrum. Biol. Plant. 1994, 36, 317-319. [CrossRef]

27. Kazemi, M. Effect of foliar application with salicylic acid and methyl jasmonate on growth, flowering, yield and fruit quality of tomato. Bull. Environ. Pharmacol. Life Sci. 2014, 3, 154-158.

28. Maciejewska, B.; Kopcewicz, J. Inhibitory effect of methyl jasmonate on flowering and elongation growth in Pharbitis nil. J. Plant Growth Regul. 2002, 21, 216-223. [CrossRef]

29. Pak, H.; Guo, Y.; Chen, M.; Chen, K.; Li, Y.; Hua, S.; Shamsi, I.; Meng, H.; Shi, C.; Jiang, L.; et al. The effect of exogenous methyl jasmonate on the flowering time, floral organ morphology, and transcript levels of a group of genes implicated in the development of oilseed rape flowers (Brassica napus L.). Planta 2009, 231, 79-91. [CrossRef]

30. Jásik, J.; De Klerk, G.J. Effect of methyl jasmonate on morphology and dormancy development in lily bulblets regenerated in vitro. J. Plant Growth Regul. 2006, 25, 45-51. [CrossRef]

31. Podwyszyńska, M.; Kosson, R.; Treder, J. Polyamines and methyl jasmonate in bulb formation of in vitro propagated tulips. Plant Cell Tissue Organ Cult. 2015, 123, 591-605. [CrossRef]

32. Mikiciuk, G.; Sas-Paszt, L.; Mikiciuk, M.; Derkowska, E.; Trzciński, P.; Głuszek, S.; Lisek, A.; Wera-Bryl, S.; Rudnicka, J. Mycorrhizal frequency, physiological parameters, and yield of strawberry plants inoculated with endomycorrhizal fungi and rhizosphere bacteria. Mycorrhiza 2019, 29, 489-501. [CrossRef]

33. Kalaji, H.M.; Bosa, K.; Kościelniak, J.; Żuk-Gołaszewska, K. Effects of salt stress on photosystem II efficiency and CO2 assimilation of two Syrian barley landraces. Environ. Exp. Bot. 2011, 73, 64-72. [CrossRef] 
34. Manimaran, P.; Ghosh, S.; Priyanka, R. Bulb size and growth regulators on the growth and performance of bulbous ornamental crops-A review. Chem. Sci. Rev. Lett. 2017, 6, 1277-1284.

35. Salachna, P.; Grzeszczuk, M.; Soból, M. Effects of chitooligosaccharide coating combined with selected ionic polymers on the stimulation of Ornithogalum saundersiae growth. Molecules 2017, 22, 1903. [CrossRef] [PubMed]

36. Ramzan, F.; Younis, A.; Riaz, A.; Ali, S.; Siddique, M.I.; Lim, K.B. Pre-planting exogenous application of gibberellic acid influences sprouting, vegetative growth, flowering, and subsequent bulb characteristics of 'Ad-Rem' tulip. Hortic. Environ. Biotechnol. 2014, 55, 479-488. [CrossRef]

37. Sauter, M.; Kende, H. Gibberellin-induced growth and regulation of the cell division cycle in deepwater rice. Planta 1992, 188, 362-368. [CrossRef] [PubMed]

38. Diallo, A.O.; Agharbaoui, Z.; Badawi, M.A.; Ali-Benali, M.A.; Moheb, A.; Houde, M.; Sarhan, F. Transcriptome analysis of an mvp mutant reveals important changes in global gene expression and a role for methyl jasmonate in vernalization and flowering in wheat. J. Exp. Bot. 2014, 65, 2271-2286. [CrossRef]

39. Mishra, S.K.; Mishra, S.; Bahadur, V. Effect of growth regulators on growth, yield and shelf life in amaryllis lily (Amaryllis belladona) cv. Zephyranthes. J. Pharmacogn. Phytochem. 2019, 8, 1217-1219.

40. Fortanier, E.J.; Van Brenk, G.; Wellensiek, S.J. Growth and flowering of Nerine flexuosa alba. Sci. Hortic. 1979, 11, 281-290. [CrossRef]

41. Brown, N.R. The Reproductive Biology of Nerine (Amaryllidaceae). Ph.D. Thesis, University of Tasmania, Tasmania, Australia, 1999.

42. Zhai, Q.; Zhang, X.; Wu, F.; Feng, H.; Deng, L.; Xu, L.; Zhang, M.; Wang, Q.; Li, C. Transcriptional mechanism of jasmonate receptor COI1-mediated delay of flowering time in Arabidopsis. Plant Cell 2015, 27, 2814-2828.

43. Cig, A.; Basdogan, G. In vitro propagation techniques for some geophyte ornamental plants with high economic value. Int. J. Second. Metab. 2015, 2, 27-49.

44. Pogroszewska, E.; Laskowska, H.; Durlak, W. The effect of gibberellic acid and benzyladenine on the yield of (Allium karataviense Regel.) 'Ivory Queen'. Acta Sci. Pol. Hortorum Cultus 2007, 6, 15-19.

45. Liu, H.; Deng, R.; Huang, C.; Cheng, Z.; Meng, H. Exogenous gibberellins alter morphology and nutritional traits of garlic (Allium sativum L.) bulb. Sci. Hortic. 2019, 246, 298-306. [CrossRef]

46. Rademacher, W. Chemical regulators of gibberellin status and their application in plant production. In Annual Plant Reviews; Wiley-Blackwell: Hoboken, NJ, USA, 2016; Volume 49, pp. 359-404.

47. Žel, J.; Debeljak, N.; Ucman, R.; Ravnikar, M. The effect of jasmonic acid, sucrose and darkness on garlic (Allium sativum L. cv. Ptujski jesenski) bulb formation in vitro. In Vitro Cell. Dev. Biol. Plant 1997, 33, $231-235$. [CrossRef]

48. Santos, I.; Salema, R. Promotion by jasmonic acid of bulb formation in shoot cultures of Narcissus triandrus L. J. Plant Growth Regul. 2000, 30, 133-138. [CrossRef]

49. Nojiri, H.; Yamane, H.; Seto, H.; Yamaguchi, I.; Murofushi, N.; Yoshihara, T.; Shibaoka, H. Qualitative and quantitative analysis of endogenous jasmonic acid in bulbing and non-bulbing onion plants. Plant Cell Physiol. 1992, 33, 1225-1231.

50. Kumudini, B.S.; Patil, S.V. Role of plant hormones in improving photosynthesis. In Photosynthesis, Productivity and Environmental Stress; Ahmad, P., Ahanger, M.A., Alam, P., Alyemeni, M.N., Eds.; John Wiley \& Sons Ltd.: Hoboken, NJ, USA, 2019; pp. 215-240.

51. Arteca, R.N. Manipulation of growth and photosynthetic processes by plant growth regulators. In Plant Growth Substances; Arteca, R.N., Ed.; Springer: Boston, MA, USA, 1996; pp. 240-272.

52. Peng, S.; Krieg, D.R.; Girma, F.S. Leaf photosynthetic rate is correlated with biomass and grain production in grain sorghum lines. Photosynth. Res. 1991, 28,1-7. [CrossRef]

53. Ahmadi, F.I.; Karimi, K.; Struik, P.C. Effect of exogenous application of methyl jasmonate on physiological and biochemical characteristics of Brassica napus L. cv. Talaye under salinity stress. S. Afr. J. Bot. 2018, 115, 5-11. [CrossRef]

54. Tavallali, V.; Karimi, S. Methyl jasmonate enhances salt tolerance of almond rootstocks by regulating endogenous phytohormones, antioxidant activity and gas-exchange. J. Plant Physiol. 2019, 234, 98-105. [CrossRef] [PubMed]

55. Miller, W.B. A review of carbohydrate metabolism in geophytes. Acta Hortic. 1992, 325, 239-246. [CrossRef] 
56. Wakchaure, G.C.; Minhas, P.S.; Meena, K.K.; Singh, N.P.; Hegade, P.M.; Sorty, A.M. Growth, bulb yield, water productivity and quality of onion (Allium cepa L.) as affected by deficit irrigation regimes and exogenous application of plant bio-regulators. Agric. Water Manag. 2018, 199, 1-10. [CrossRef]

57. Sarkar, D.; Pandey, S.K.; Sharma, S. Cytokinins antagonize the jasmonates action on the regulation of potato (Solanum tuberosum) tuber formation in vitro. Plant Cell Tissue Organ Cult. 2006, 87, 285-295. [CrossRef]

58. Theron, K.I.; Jacobs, G. Changes in carbohydrate composition of the different bulb components of Nerine bowdenii W. Watson (Amaryllidaceae). J. Amer. Soc. Hort. Sci. 1996, 121, 343-346. [CrossRef]

(C) 2020 by the authors. Licensee MDPI, Basel, Switzerland. This article is an open access article distributed under the terms and conditions of the Creative Commons Attribution (CC BY) license (http://creativecommons.org/licenses/by/4.0/). 